\title{
Evaluation of Fungicides for Management of Powdery Mildew (Erysiphecichoracearum) on Vernonia (Vernonia Galamensis)
}

\author{
Niguse Hundesa ${ }^{1}$, Mihiret Mekonnen ${ }^{2}$ \\ ${ }^{1}$ Kulumsa Agricultural Research Center, EIAR, P.O.Box. 419 Asella, Ethiopia. \\ ${ }^{2}$ Wondo Genet Agricultural Research Center, EIAR, P.O. Box. 198, Shashemene, Ethiopia.
}

\begin{abstract}
Vernonia galamensis ssp. galamensis var. ethiopicais a new annual industrial oilseed crop. 'vernonia oil' used in the chemical (glue, paint and plastics), pharmaceutical and agro-industrial industries. Powdery mildew caused by Erysiphecichoracearum is major problem of Vernonia production in southern parts of Ethiopia.It causes severe wilting, death of leaves, premature defoliation, and growth reduction andpermanent damage of the crop. It may occur at any time during the growing season; however, it is usually most severe in the late summer months. Therefore, the aim of this study was to evaluate the efficacyof some registered fungicides for the management of powdery mildew on Vernonia. The experiment was laid out in randomized complete block design $(R C B D)$ with three replications. A plot size of $3 m \times 3 m$ with $50 \mathrm{~cm} \times 50 \mathrm{~cm}$ spacing between plants was used. Fungicides cymoxinil + copper oxychloride, Propiconazole, Mancozeb, Spiroxamine $500 \mathrm{gm} / \mathrm{lt}$ and Thiophanate Methyl were applied at recommended rate as treatments and untreated control.Data on disease incidence, severity, disease control, seed yield and oil yield were recorded.Foliarapplications of treatments were made 2015 and 2016.Among treatments, the degree of powdery mildew control ranged from 66.33 to zero (untreated control); however, all treatments significantly reduced disease severity compared to untreated plants. Among all products tested for the control of powdery mildew; Cymoxinil + Copper oxychloride and //.Thiophanate Methyl were higher than the rest of chemicals tested.Highest significant disease severity ( $p \leq 0.05$ ) was also achieved with these fungicides which reduced the disease severity to 8.8 and $9.13 \%$ respectively as compared to $24 \%$ in control. Therefore, Cymoxinil + Copper oxychloride and Thiophanate Methyl were more effective for management of powdery mildew in field conditions.
\end{abstract}

Keywords: Chemicals, Disease control, Oleoresin, Powdery mildew, Vernonia.

\section{INTRODUCTION}

Vernonia galamensis(Cass.) Less. is a relatively new industrial crop in many parts of Africa. Most ofVernoniaspecies occur in South America but more than 300 species from Africa have been described with most occurring in Ethiopia and Madagascar. The genus vernonia comprises of more than a thousand species whichvary from annual herbs and shrubs to perennial trees (Baye et al.,2001). There are six major subspecies namely afromontana, galamensis, gibbosa, nairobensis, lushotoensis and mutomonesis. Among these, galamensiss hows the highest genetic diversity (Gilbert, 1986). It contains four botanical varieties namely australis, ethiopica, galamensis and petitiana(Gilbert, 1986)

Vernonia galamensis ssp. galamensis var. ethiopicais a new annual industrial oilseed. It grows naturally in marginal areas with as little as $200 \mathrm{~mm}$ seasonal rainfall and at an elevation ranging from 700-2400 $\mathrm{m}$ in the southern and southeastern parts of Ethiopia (Gilbert 1986). It was first identified in eastern Ethiopia by R.E. Perdue Jr. in 1964 at $7 \mathrm{~km}$ south east of Harar town $\left(9^{\circ} 14^{\prime} \mathrm{N}\right.$ and $42^{\circ} 35^{\prime} \mathrm{E}$ at $1700 \mathrm{~m}$ ). It has unique properties which make it interesting both economically and ecologically (Perdue 1988).

Vernonia galamensis primarily distributed to Eastern Africa, which is grown in a wild form in Eritrea, Ethiopia, Malawi, Tanzania and Kenya. This African species, V. galamensis seed oil contained 42\% and $80 \%$ vernolic acid considerably higher than any selection of Vernonia anthelmintica originating from India (Thompson, 1990).

Traditionally, Vernonia galamensis is considered a weed. The high oil content of the seed and the high content of vernolic acid in the oil make it a potential oil crop. The oil, called 'vernonia oil' can be used in the chemical (glue, paint and plastics), pharmaceutical and agro-industrial industries. In the 
paint industry it is being tested as a component of low volatile-organic-solvent paints. As a component of heat-baked films and coatings, vernonia oil provides outstanding adhesion, flexibility and chipping resistance, and good resistance to alkaline, acid and non-polar solvents. In plastics it can be used as a plasticizer of PVC and as a structural component of polymers (Bayeetal, 2007).

Vernonia as potential use a petroleum substitute is important since the demand for petroleum each year in the U.S. is approximately 8,500 lbs per person, of which about $500 \mathrm{lbs}$ per person is needed for production of plastics and industrial petrochemicals (Teynor et al., 1992).

Pests and pathogens can drastically reduce growth and productivity of a crop. Limited research has been undertaken to gain insight on pests and pathogen interactions with vernonia. Vernonia

has been documented to associate with a number of diseases and pests. Some pathogens have over time co-evolved with V. galamensis and are specific to it. Collection and preliminary identification by Baye and Gudeta (2002) of the pest species associated with vernonia in Ethiopia indicated that various pest insects, pathogenic fungi and bacteria were associated with vernonia.

Damping-off caused serious losses in seedling survival (over 10\%). Powdery mildew caused severe wilting and death of leaves late in the growing period, especially during flowering. Aspergillus niger, Penicillium sp. Cladosporium sp.,Pythium sp.,Fusarium sp.,Rhizoctoniasolani, Alternaria sp. and Phoma sp. have also been reported elsewhere as disease causal agents in V. galamensis (Tefera and Baye, 2003)

Powdery mildews are easily recognized by the white, powdery growth of the fungus on infected portions of the plant host. The powdery appearance results from the superficial growth of the fungus as threadlike strands (hyphae) over the plant surface and the production of chains of spores (conidia). Colonies vary in appearance from fluffy and white to sparse and gray. Powdery mildew fungi usually attack young developing shoots, foliage, stems, and flowers but can also colonize mature tissues. Symptoms often first appear on the upper leaf surface but can also develop on lower leaf surfaces, which are followed by the typical white, powdery appearance. Other symptoms include atypical scablike lesions, witches'-brooms, twisting and distortion of newly emerging shoots, premature leaf coloration and drop, slowed or stunted growth, and leaf rolling. In rare but extreme situations, heavy infections cause plant death. Although diagnosis of powdery mildew is not difficult, symptoms often escape early detection if plants are not periodically monitored since symptoms can first develop on lower or middle leaves (Mahaffee et al. 2009).

AlthoughPowdery mildews cause growth reduction,severe wilting and death of leaves late in the growing period, especially during flowering,chemicals as alternative management not yet evaluated. Thus the aim of this study was to evaluate chemicals for the management of powdery mildew on Vernonia galamensis.

\section{Materials AND Methods}

This study was conducted at Wondo Genet Agricultural Research Center experimental field, in $2015 / 16$ cropping season. The site is located at $7^{\circ} 192^{\prime} \mathrm{N}$ latitude and $38^{\circ} 382^{\prime}$ E longitudes with an altitude of $1780 \mathrm{~m}$ above sea level. The site receives a mean annual rainfall of $1000 \mathrm{~mm}$ with minimum and maximum temperatures of 10 and $30^{\circ} \mathrm{C}$, respectively. The soil textural class is clay loam with an average $\mathrm{PH}$ of 7.2.

The experiment waslaid out in randomized complete block design (RCBD) with three replications. A plot size of $3 \mathrm{~m} \times 3 \mathrm{~m}$ with $50 \mathrm{~cm} \times 50 \mathrm{~cm}$ spacing between plants was used. Spacing between plots and blocks was $1.5 \mathrm{~m}$ and $2 \mathrm{~m}$, respectively to minimize the chemical drift.

Healthy planting materials were planted at the beginning of the main rainy season. Chemicals cymoxinil + copper oxychloride, Propiconazole, Mancozeb, Spiroxamine 500gm/lt and Thiophanate Methyl were sprayed at recommended rate as treatments and untreated control. The candidate fungicides were applied manually using knapsack sprayer on sunny weather day in the morning fifty day interval at recommended rate. The severity of powdery mildew was determined by rating 10 plants in the middle of each of the three replicated plots per treatment using the following rating system: $0=$ no powdery mildew present; 1 = powdery mildew present on bottom leaves of plant $1-5 \%$; 2 =powdery mildew present on bottom leaves $5-10 \% ; 3=$ powdery mildew present $10-25 ; 4=$ powdery mildew present on leaves $25-50,5=$ powdery mildew present on entire leaves $50-100 \%$. 
Evaluation of Fungicides for Management of Powdery Mildew (Erysiphecichoracearum) on Vernonia (Vernonia Galamensis)

Table 1. Fungicides and their rate and recommended used in the study.

\begin{tabular}{|c|c|c|c|}
\hline Treatments & Product & $\begin{array}{l}\text { Registered } \\
\text { field rate }\end{array}$ & Recommended \\
\hline Curzate R WP & $\begin{array}{l}\text { DupontDilimoures SAS } 75334 \\
\text { paricsedex 07 Franc }\end{array}$ & $200-300 \mathrm{~g} / 1001$ & $\begin{array}{l}\text { Late blight, early blight and downy } \\
\text { mildew }\end{array}$ \\
\hline $\begin{array}{l}\text { Impulse } \quad \mathrm{EC} \\
500\end{array}$ & BAYEF crop science AG. & & Powdery mildew and rust \\
\hline Tilt $250 \mathrm{EC}$ & $\begin{array}{l}\text { Syngent crop protection } \mathrm{AG} \\
\text { Basle, Switzer land }\end{array}$ & $0.51 / \mathrm{ha}$ & $\begin{array}{l}\text { Rust, Septoria, Powdery mildew, } \\
\text { Eye spot, Net blotch, Scalde, }\end{array}$ \\
\hline $\begin{array}{l}\text { Mancozeb } 80 \\
\text { WP }\end{array}$ & $\begin{array}{l}\text { According FRAC classification } \\
\text { group } \mathrm{M}_{3} \text {. }\end{array}$ & $30 \mathrm{~g} / 151$ & $\begin{array}{l}\text { Mildew, Anthracnose, Botrytis, Late } \\
\text { blight, Rust }\end{array}$ \\
\hline Methyl & Methyl benzimidazole & $1-1.51 / \mathrm{ha}$ & Powdery mildew, blight and scab \\
\hline $\begin{array}{l}\text { Untreated } \\
\text { control }\end{array}$ & - & - & - \\
\hline
\end{tabular}

\subsection{Data Collection and Statistical Analysis}

Data on disease incidence, severity, disease control, seed yield and oil yield were recorded. The collected data were analyzed using analysis of variance using SAS software version 9.2. Means was separated using LSD at $\mathrm{P}=0.05$.

\section{RESUlT AND DISCUSSION}

Analysis of variance result indacated that there was statistcaly significant difrenceces among treatments in diseases severity, diseases control and Oleoresin, however non-significant differences existed in seed yields.

The data in the table 2 illustrate the degree of control obtained by applications of fungicides tested in this trial. Among treatments, the degree of powdery mildew control ranged from 66.33 to zero (untreated control); however, all treatments significantly reduced disease severity compared to untreated plants. Among all products tested for the control of powdery mildew; Cymoxinil + Copper oxychloride and Thiophanate Methyl were higher than the rest of chemicals tested.

The level of reduction of disease severity in this trial varied among treatments. Highest significant disease severity $(\mathrm{p} \leq 0.05)$ was achieved with aCymoxinil + Copper oxychloride andThiophanate Methyl, which reduced the disease severity to 8.8 and $9.13 \%$ respectively as compared to $24 \%$ in control. Statistically there was non-significant difference in diseases severity among the fungicidesSpiroxamine 500gm/lt, Propiconazole and Mancozeb, however all these three fungicides reduced the severity of diseasesover control significantly when applied in recommended rate.

In the present study, application of Cymoxinil + Copper oxychloride and Thiophanate Methyl, were the most effective fungicidal treatment for reduction of foliar symptoms of powdery mildew as evidenced by reduced disease severity and highest disease control values. Phytotoxicity symptoms were not noted on Vernonia for any of the materials tested. Mahaffee et al. 2009 also stated that successful control of powdery mildew with fungicide is dependent on early application practices to keep the disease presence as low as possible.

This trial also revealed that there was non-significant difference among treatments in seed yield of Vernonia on the plots throughout the replications. The highest disease pressure occurrence after flowering didn't affect seed yield however resulted in the loss quality as well. Similarly Mahaffee et al. 2009 stated thateven low disease levels, particularly in aroma varieties, can result in a loss of cone quality to the point where the crop will be rejected by brewers with fungicides that have a low risk.

Disease incidence was lower in the cymoxinil + copper oxychloride , Mancozeb and Thiophanate Methyl treatment than in the untreated control. A clear decrease in disease incidence and disease severity was observed in the cymoxinil + copper oxychloride, Mancozeb and Thiophanate and have highest oleoresin receded in treatment because of the emergence of new leaves that had not become infected.

Normally, seed yield and oleoresin were higher in treated plants than untreated control. The disease severity levels were high on untreated plants with decreasing oleoresin. There was a clear negative correlation between the level of disease severity and oleoresin. 


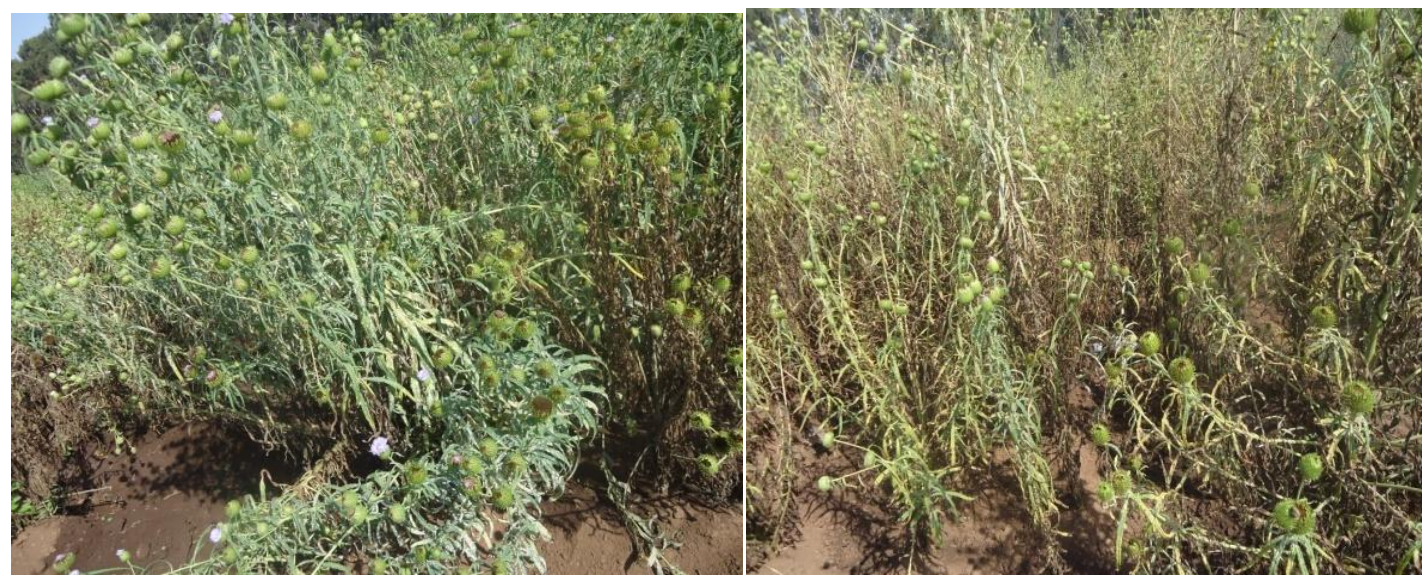

A. Curzate R WP

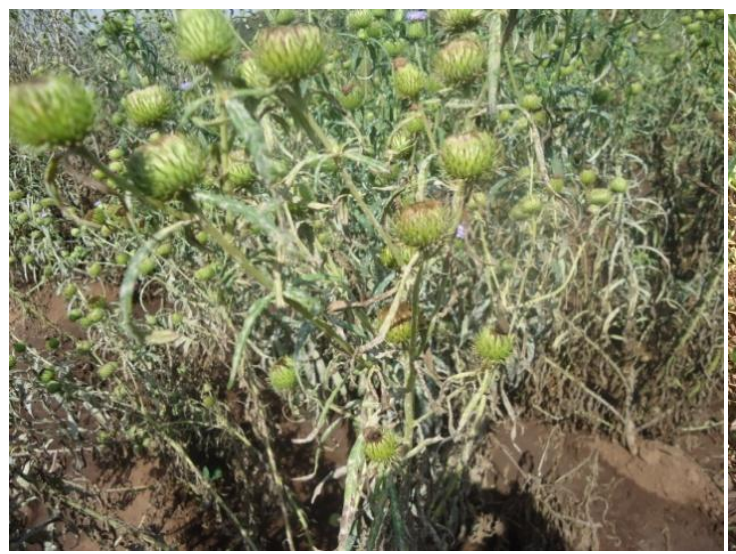

C. Topsin-M 70WP
B. Control

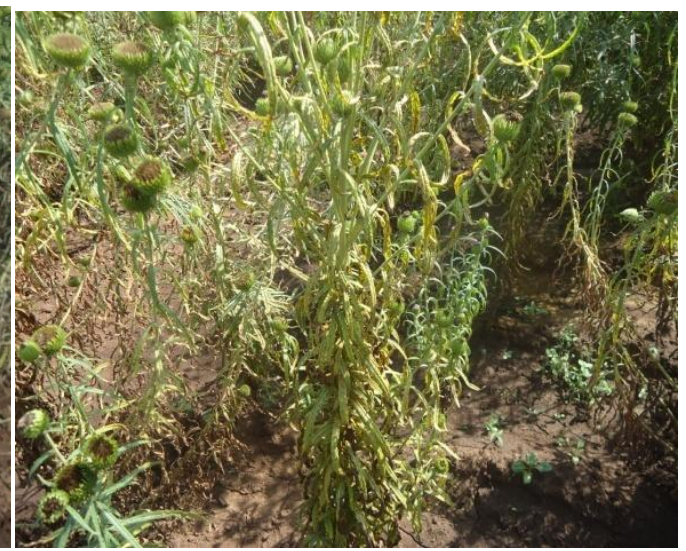

D. ImpulseEC 500

Table 2. Efficacy of different tested fungicides for the control of vernonia in field condition.

\begin{tabular}{|c|c|c|c|c|c|c|c|}
\hline $\begin{array}{l}\text { Trade } \\
\text { name }\end{array}$ & $\begin{array}{l}\text { Common } \\
\text { name }\end{array}$ & Active ingredients & Yield & Oleoresin & DS & $\begin{array}{l}\text { DI } \\
(\%)\end{array}$ & $\overline{\mathrm{DC}}$ \\
\hline $\begin{array}{ll}\text { Curzate } & \mathrm{R} \\
\text { WP } & \end{array}$ & $\begin{array}{l}\text { cymoxinil + } \\
\text { copper } \\
\text { oxychloride }\end{array}$ & $\begin{array}{ll}\text { Cymoxinil-4.2\%,copper } & \\
\text { oxychloride- } & \\
68.95 \% \text { (equvalent } & \text { to } \\
39.75 \% \text { metalic copper } & \end{array}$ & $18.00^{\mathrm{a}}$ & $35.60^{b}$ & $8.80^{\mathrm{c}}$ & $10^{\mathrm{c}}$ & $63.33^{\mathrm{a}}$ \\
\hline $\begin{array}{l}\text { ImpulseEC } \\
500\end{array}$ & $\begin{array}{l}\text { Spiroxamine } \\
500 \mathrm{gm} / \mathrm{lt}\end{array}$ & Emulsifiable concentrate & $17.63^{\mathrm{a}}$ & $33.90^{\mathrm{c}}$ & $13.46^{\mathrm{b}}$ & $15^{\mathrm{b}}$ & $43.88^{\mathrm{b}}$ \\
\hline Tilt 250 EC & Propiconazole & 250g/lt.propiconazole & $17.86^{\mathrm{a}}$ & $36.10^{b}$ & $12.26^{\mathrm{b}}$ & $12^{\mathrm{c}}$ & $48.88^{\mathrm{b}}$ \\
\hline $\begin{array}{l}\text { Mancozeb } \\
80 \mathrm{WP}\end{array}$ & Mancozeb & $\begin{array}{l}\text { Mancozeb- } 800 \mathrm{~g} / \mathrm{kg} \\
\text { Other- } 200 \mathrm{~g} / \mathrm{kg}\end{array}$ & $17.02^{\mathrm{a}}$ & $39.10^{\mathrm{a}}$ & $13.73^{\mathrm{b}}$ & $10^{\mathrm{c}}$ & $42.77^{\mathrm{b}}$ \\
\hline $\begin{array}{l}\text { Topsin-M } \\
\text { 70WP }\end{array}$ & $\begin{array}{l}\text { Thiophanate } \\
\text { Methyl }\end{array}$ & $\begin{array}{l}\text { (dimethyl[ 1,2-phenylene]- } \\
\text { bis (iminocabonothioyl]bis } \\
\text { (carbamate] } 70 \% \text { and other } \\
30 \%\end{array}$ & $19.10^{\mathrm{a}}$ & $34.60^{b}$ & $9.13^{\mathrm{c}}$ & $12^{\mathrm{c}}$ & $61.94^{\mathrm{a}}$ \\
\hline $\begin{array}{l}\text { Un treated } \\
\text { control }\end{array}$ & & & $16.40^{\mathrm{a}}$ & $31.90^{\mathrm{d}}$ & $24.00^{\mathrm{a}}$ & $20^{\mathrm{a}}$ & $0.00^{c}$ \\
\hline $\mathrm{CV}$ & & & 27.87 & 3.13 & 6.79 & 7.6 & 8.79 \\
\hline LSD & & & 8.96 & 1.99 & 1.66 & 1.99 & 6.95 \\
\hline
\end{tabular}

Means with the same letter within the same column are not statistically different $(p<0.05)$. Where, Ds- disease severity, DI- disease incidence and DC- disease control.

\section{Conclusion}

Among investigated fungicides Cymoxinil + Copper oxychloride and Thiophanate Methyl was effective candidate for the control of powdery mildew on Vernonia galamensis in field conditions. Those selected chemical showed varying antifungal activity against Vernonia galamensis powdery mildew. Further study should be conducted under typical conditions by varying the stage of plant growth. 


\section{ACKNOWLEDGEMENTS}

Authors thank Wondo Genet Agricultural Research Center and Aromatic and Medicinal plants Research project for providing all the necessary facilities and National Plant Protection Research Case Team Coordinator for providing a research fund.

\section{REFERENCES}

[1]. Baye T, Becker HC, Witzke - Ehbrecht S von 2000. Vernonia galamensis, a new industrial crop for the semiarid tropics and subtropics. 3rd Int. Crop SciCongr.17-22 Aug. 2000, Hamburg, Germany.

[2]. Cowall M, May H 1995. Copper fungicide disease control options. Vegetable Update. Cornell Cooperative Extension of Oswego County, NY.July 25,p. 11.

[3]. Gilbert, MG 198). Notes on eastern Africa Vernonia (Compositae). IV. A revision of the Vernonia galamensis complex. Kew Bul. 41(1):19-35.

[4]. Mahaffee W, Engelhard B, Gent DH, \& Grove GG 200). Powdery Mildew.Compendium of Hop Diseases and Pests (pp. 25-31). St. Paul, Minnesota: The American Phytopathological Society.

[5]. Perdue, RE 1988. Systematic botany in the development of Vernonia galamensis as a new industrial oilseed crop for the semi-arid tropics. Symbolae Botanicae UpsaliensisXXVII (3):125135.

[6]. Baye T, Tesfaye M. \& Oyen LPA 2007.Vernonia galamensis (Cass.) Less. [Internet] Record from PROTA4U. van der Vossen, H.A.M. \&Mkamilo, G.S. (Editors). PROTA (Plant Resources of Tropical Africa / Resources végétales de l'Afriquetropicale), Wageningen, Netherlands. $<$ http://www.prota4u. org/search.asp>. Accessed 29 November 2016

[7]. Baye T, Gudeta S 2002. Pest Survey of Vernonia galamensis in Ethiopia. Trends in New Crops and New Uses.ASHS Press.1-3.

[8]. Tefera T, Baye T 2003. Mycoflora Associated with New Industrial Oilseed Crop (Vernonia galamensisvar. ethiopica ) in Ethiopia. Tropical Science 43, 6-9.

[9]. Thompson AE 1990. Arid-land Industrial Crops. In Janick J, Simon JE (ed.) Advances in New Crops. Timber Press, Portland OR. pp. 232-241.

[10]. Teynor TM, Putman DH, Oplinger ES, Oelke EA, Kelling KA, Doll JD 1992. Vernonia. Alternative Field Crops Manual. Center for Alternative Plant and Animal Products, University of Wisconsin- Extension and Cooperative Extension, University of Minnestoa. 